\title{
Synthesis and Biological Evaluation of Focused Isoxazolylpiperidinylpiperazine Library for Dopamine $D_{3}$ and $D_{4}$ Receptor Antagonists
}

\author{
Kamalkishor P. Landge, Ji Seon Oh, ${ }^{\dagger}$ Ae Nim Pae, ${ }^{\ddagger}$ Woo Kyu Park, ${ }^{\S}$ Jae Yang Gong, ${ }^{\S}$ \\ Hun Yeong Koh, ${ }^{*}$ and Sun Ho Jung ${ }^{\dagger, *}$ \\ Department of Chemistry, Inha University, Nam-gu, Incheon 402-751, Korea. *E-mail: hykoh@inha.ac.kr \\ †Department of Chemistry, Sungshin Women's University, Seoul 136-742, Korea. EE-mail: shjung@sungshin.ac.kr \\ ${ }^{\star}$ Neuro-Medicine Center, Korea Institute of Science and Technology, Seoul 136-791, Korea \\ ${ }^{\S}$ Pharmaceutical Screening Research Team, Korea Research Institute of Chemical Technology, Daejon 305-343, Korea \\ Received April 7, 2011, Accepted May 9, 2011
}

Key Words : Dopamine receptor, Isoxazolylpiperidinylpiperazine, Antagonist, GPCR

The dopamine receptor system plays a key role in numerous neuropsychiatric and neurological disorders. The $\mathrm{D}_{3}$ receptor, first described in $1990,{ }^{1}$ is a member of the $\mathrm{D}_{2}$-like receptor family, and possesses about $50 \%$ overall homology to the $\mathrm{D}_{2}$ receptor subtype. ${ }^{2} \mathrm{D}_{3}$ receptors are localized in the limbic areas of the brain, specifically in the group of neural granule cells located within the ventral striatum in the brains of most animals. ${ }^{3}$ In the field of medicinal chemistry extensive efforts have been made to explore potent and selective ligands for dopamine $\mathrm{D}_{3}{ }^{1}$ or $\mathrm{D}_{4}{ }^{4}$ receptor for the discovery of antipsychotic drugs. ${ }^{5}$ Currently, much research effort is being focused on the discovery of highly selective dopamine $\mathrm{D}_{4}$ receptor ligands. ${ }^{6}$ The reason for the interest in this area is derived from the possible involvement of $\mathrm{D}_{4}$ receptor in schizophrenia. $^{7-10}$ In connection with search for selective ligands for various GPCRs, we have recently reported ${ }^{11}$ the design and synthesis of arylpiperazine derivative libraries as dopamine receptor antagonist and serotonine receptor antagonist with isoxazole rings. In continuation of our efforts to search for selective GPCR ligands, we envisaged a library of piperidinylpiperazine derivatives with isoxazole rings as a plausible candidate for the purpose. Herein we wish to report the construction of a small focused library of isoxazolylpiperidinylpiperazines and their binding affinities for dopamine $\mathrm{D}_{3}$ and $\mathrm{D}_{4}$ receptors.

The synthesis of isoxazolylpiperidinylpiperazine derivatives is shown in Schemes 1, 2 and 3. The synthetic strategy to these compounds involved reductive amination between two building blocks 5 and 9.

For the acquisition of building block $\mathbf{5}$, the amino group of

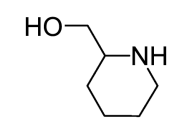

1

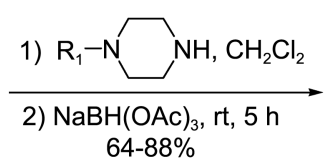

$64-88 \%$

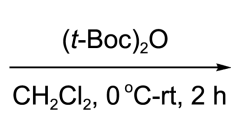

$90 \%$

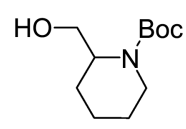

2

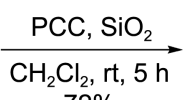

$72 \%$

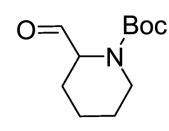

3

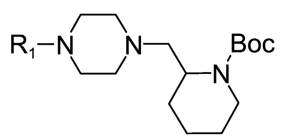

4

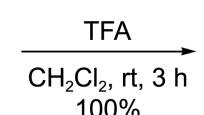

$100 \%$

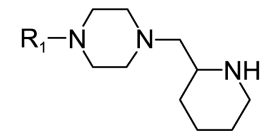

5

Scheme 1. Synthesis of building block 5 .
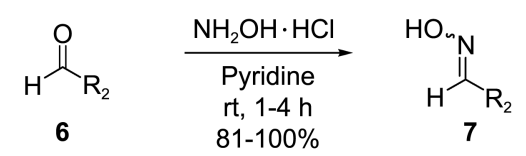
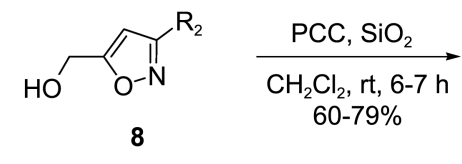

Scheme 2. Synthesis of building block 9.

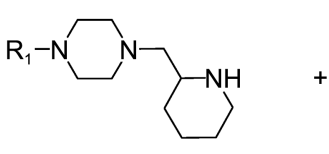

5<smiles>[R]c1cc(C=O)on1</smiles>

9

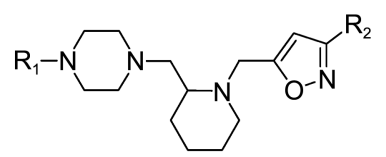

10

Scheme 3. Synthesis of scaffold (isoxazolylpiperidinylpiperazine). 
Table 1.

\begin{tabular}{|c|c|c|c|c|}
\hline Entry & $\mathrm{R}^{1}$ & $\mathrm{R}^{2}$ & Compound & Yield $^{a} \%$ \\
\hline 1 & & & $10-1$ & 53.5 \\
\hline 2 & & & $10-2$ & 56.8 \\
\hline 3 & & & $10-3$ & 64.6 \\
\hline 4 & & & $10-4$ & 18.2 \\
\hline 5 & & & $10-5$ & 67.9 \\
\hline 6 & & & $10-6$ & 75.0 \\
\hline 7 & & A & $10-7$ & 54.9 \\
\hline 8 & & B & $10-8$ & 51.3 \\
\hline 9 & & $\mathrm{C}$ & $10-9$ & 65.4 \\
\hline 10 & & $\mathrm{D}$ & $10-10$ & 28.9 \\
\hline 11 & & $\mathrm{E}$ & $10-11$ & 36.7 \\
\hline 12 & & $\mathrm{~F}$ & $10-12$ & 20.8 \\
\hline 13 & & B & $10-13$ & 13.7 \\
\hline 14 & & $\mathrm{D}$ & $10-14$ & 11.0 \\
\hline 15 & & A & $10-15$ & 13.0 \\
\hline 16 & & B & $10-16$ & 58.0 \\
\hline 17 & & $\mathrm{C}$ & $10-17$ & 70.8 \\
\hline 18 & & $\mathrm{D}$ & $10-18$ & 16.0 \\
\hline 19 & & $\mathrm{E}$ & $10-19$ & 61.9 \\
\hline 20 & & $\mathrm{~F}$ & $10-20$ & 13.0 \\
\hline 21 & & D & $10-21$ & 73.7 \\
\hline 22 & & $\mathrm{~A}$ & $10-22$ & 45.2 \\
\hline 23 & & B & $10-23$ & 10.0 \\
\hline 24 & & $\mathrm{D}$ & $10-24$ & 23.3 \\
\hline 25 & & $\mathrm{D}$ & $10-25$ & 87.1 \\
\hline 26 & & $\mathrm{D}$ & $10-26$ & 63.5 \\
\hline 27 & & $\mathrm{D}$ & $10-27$ & 71.9 \\
\hline
\end{tabular}

${ }^{a}$ Isolated yield after column chromatography. piperidin-2-ylmethanol 1 was first protected by $(t-\mathrm{Boc})_{2} \mathrm{O}$ in dichloromethane at $0{ }^{\circ} \mathrm{C}$ and then at $\mathrm{rt}$ to give compound $\mathbf{2}$ in $90 \%$ yield. Compound 2 was then oxidized with PCC and $\mathrm{SiO}_{2}$ in dichloromethane at $\mathrm{rt}$ for $5 \mathrm{~h}$ into aldehyde 3 in $72 \%$ yield. The aldehyde 3 was reacted with piperazine derivatives using $\mathrm{NaBH}(\mathrm{OAc})_{3}$ in presence of $4 \AA$ molecular sieve over $5 \mathrm{~h}$ to afford compounds 4 in $64-88 \%$ yields. Finally building block 5 was obtained in quantitative yield by a simple deprotection reaction with $\mathrm{CF}_{3} \mathrm{CO}_{2} \mathrm{H}$ in dichloromethane at rt.

With building block 5 in hand, we moved to our next building block 9 . Treatment of aldehydes $\mathbf{6}$ with hydroxylamine hydrochloride and pyridine at $\mathrm{rt}$ for $1-4 \mathrm{~h}$ gave oximes 7 in $81-100 \%$ yields. Isoxazole nucleus was generated by two-step sequence of nitrile oxide cycloaddition reaction which involved (1) chlorination of 7 with $N$-chlorosuccinimide and (2) in situ generation of nitrile oxide and cycloaddition with propargyl alcohol. In this way isoxazole alcohols 8 were obtained in 50-81\% yields. Subsequent PCC oxidation of 8 afforded building block 9 in $60-79 \%$ yields.

Table 2. In vitro biological data of isoxazolylpiperidinylpiperazine compounds

\begin{tabular}{|c|c|c|c|}
\hline Entry & Compound & $\begin{array}{l}\mathrm{IC}_{50}(\mu \mathrm{M}) \text { for } \mathrm{D}_{3} \\
\text { receptor }\end{array}$ & $\begin{array}{l}\mathrm{IC}_{50}(\mu \mathrm{M}) \text { for } \mathrm{D}_{4} \\
\text { receptor }\end{array}$ \\
\hline 1 & $10-1$ & 2.6 & 4.8 \\
\hline 2 & $10-2$ & $>10$ & 3.8 \\
\hline 3 & $10-3$ & 3.1 & 1.1 \\
\hline 4 & $10-4$ & 7.3 & 6.9 \\
\hline 5 & $10-5$ & 8.2 & 3.5 \\
\hline 6 & $10-6$ & 4.1 & 3.2 \\
\hline 7 & $10-7$ & 4.8 & 8.5 \\
\hline 8 & $10-8$ & $>10$ & $>10$ \\
\hline 9 & $10-9$ & 6.2 & 2.7 \\
\hline 10 & $10-10$ & 8.6 & 6.8 \\
\hline 11 & $10-11$ & 5.3 & 1.4 \\
\hline 12 & $10-12$ & 0.7 & 1.4 \\
\hline 13 & $10-13$ & 3.0 & 3.2 \\
\hline 14 & $10-14$ & 4.8 & 7.8 \\
\hline 15 & $10-15$ & 2.2 & $>10$ \\
\hline 16 & $10-16$ & $>10$ & $>10$ \\
\hline 17 & $10-17$ & 5.0 & $>10$ \\
\hline 18 & $10-18$ & 4.8 & $>10$ \\
\hline 19 & $10-19$ & $>10$ & 8.9 \\
\hline 20 & $10-20$ & $>10$ & 5.5 \\
\hline 21 & $10-21$ & $>10$ & 2.0 \\
\hline 22 & $10-22$ & $>10$ & $>10$ \\
\hline 23 & $10-23$ & 4.8 & $>10$ \\
\hline 24 & $10-24$ & 9.5 & 9.1 \\
\hline 25 & $10-25$ & 1.6 & $>10$ \\
\hline 26 & $10-26$ & 1.9 & 9.5 \\
\hline 27 & $10-27$ & 6.3 & 2.0 \\
\hline \multicolumn{2}{|c|}{ Haloperidol } & 0.062 & - \\
\hline \multicolumn{2}{|c|}{ Spiperone } & - & 0.013 \\
\hline
\end{tabular}


Employing the developed combinatorial protocol, ${ }^{12}$ synthesis of isoxazolylpiperidinylpiperazine derivatives $\mathbf{1 0}$ was finally accomplished by simple reductive amination reaction between building blocks 5 and 9 using $\mathrm{NaBH}(\mathrm{OAc})_{3}{ }^{13}$ (Scheme 3). Thus prepared isoxazolylpiperidinylpiperazine products are shown in Table 1. Structures and purities of products were confirmed by ${ }^{1} \mathrm{H} \mathrm{NMR},{ }^{13} \mathrm{C} \mathrm{NMR}$, IR, MS spectroscopic analysis and HPLC.

Thus, a small focused library of diverse compounds $\mathbf{1 0}$ was constructed and tested for binding affinities ${ }^{14}$ for dopamine $\mathrm{D}_{3}$ and $\mathrm{D}_{4}$ receptors. As shown in Table 2 most of the compounds exhibited $\mathrm{IC}_{50}$ values below $5 \mu \mathrm{M}$ which will be the key factor for further research in this field. Compound 10-3 (entry 3, when $R_{1}$ is phenyl and $R_{2}$ is 2-methoxyphenyl) showed a good activity for dopamine $\mathrm{D}_{3}(3.1 \mu \mathrm{M})$ and $\mathrm{D}_{4}(1.1 \mu \mathrm{M})$. Among the prepared compounds, compound 10-12 (entry 12, when $R_{1}$ is 2-fluorophenyl and $R_{2}$ is benzo1,3-dioxole) showed best binding affinity for dopamine $D_{3}$ receptor $(0.7 \mu \mathrm{M})$ and good activity towards $\mathrm{D}_{4}$ receptor $(1.4$ $\mu \mathrm{M}$ ). Compound 10-11 (entry 11), in which $\mathrm{R}_{2}$ of compound 10-12 is replaced by 4-methylphenyl, also exhibited good binding activities but selective affinity for $\mathrm{D}_{4}$ receptor $(1.4$ $\mu \mathrm{M})$ over $\mathrm{D}_{3}$ receptor $(5.3 \mu \mathrm{M})$. When $\mathrm{R}_{1}$ is 3-chlorophenyl a dramatic change of activity was observed as follows: While compound 10-15 (entry 15 , when both $R_{1}$ and $R_{2}$ are 3-chlorophenyl) showed good activity only towards dopamine $\mathrm{D}_{3}$ receptor $(2.2 \mu \mathrm{M})$ compared to dopamine $\mathrm{D}_{4}$ receptor $(>10 \mu \mathrm{M})$, compound $\mathbf{1 0 - 2 0}$ (entry 20 , when $R_{1}$ is 3-chlorophenyl but $\mathrm{R}_{2}$ is benzo-1,3-dioxole) exhibited completely opposite results $\left(>10 \mu \mathrm{M}\right.$ for dopamine $\mathrm{D}_{3}$ receptor and $5.5 \mu \mathrm{M}$ for dopamine $\mathrm{D}_{4}$ receptor). It is also noteworthy that compound $\mathbf{1 0 - 2 5}$ (entry 25), in which $\mathrm{R}_{1}$ is bis(fluorophenyl)methyl and $\mathrm{R}_{2}$ is 2-fluorophenyl, showed good activity $(1.6 \mu \mathrm{M})$ for dopamine $\mathrm{D}_{3}$ receptor. In our previous research $^{11 a}$ some piperazinylalkylisoxazole compounds had excellent binding affinities. We envisaged that introduction of any heterocycle with nitrogen in between piperazine and isoxazole may increase the binding affinity. However such notion proved unsuccessful in case of the heterocycle being piperidine as the binding results indicated. Nonetheless it is interesting to note that fluoro compounds show better binding affinities for dopamine $\mathrm{D}_{3}$ and dopamine $\mathrm{D}_{4}$ receptors than other derivatives.

In summary we have synthesized a small focused library of isoxazolylpiperidinylpiperazine compounds and tested them in vitro ${ }^{14}$ for dopamine $\mathrm{D}_{3}$ and $\mathrm{D}_{4}$ receptor binding affinities. The results might be helpful for the future research in the design and synthesis of potent and selective ligands for dopamine $\mathrm{D}_{3}$ or $\mathrm{D}_{4}$ receptors.

\section{Experimental Section}

General Procedure for Synthesis of Building Block 5 (when $\mathbf{R}_{\mathbf{1}}=\mathbf{P h}$ ). To a solution of compound $\mathbf{3}$ (481 mg, 2.25 $\mathrm{mmol})$ in dichloromethane $(20 \mathrm{~mL})$ at $\mathrm{rt}$, 1-phenylpiperazine (444 $\mu \mathrm{L}, 2.92 \mathrm{mmol})$ and $4 \AA$ molecular sieve were added. After the mixture being stirred for $5 \mathrm{~min}, \mathrm{NaBH}(\mathrm{OAc})_{3}$
(1.43 g, $6.74 \mathrm{mmol})$ was added and the mixture was stirred for $5 \mathrm{~h}$. Saturated $\mathrm{NaHCO}_{3}$ solution was added and the mixture was extracted with ethyl acetate $(50 \mathrm{~mL} \times 3)$. The organic layers were dried over anhydrous $\mathrm{MgSO}_{4}$ and concentrated. The residue was purified by flash column chromatography (Hexane:EtOAc $=4: 1$ ) to give the compound 4 (when $\mathrm{R}_{1}=\mathrm{Ph}, 531 \mathrm{mg}, 66 \%$ ).

To a solution of thus prepared compound 4 (447 mg, 1.24 $\mathrm{mmol})$ in dichloromethane at $\mathrm{rt}$, trifluoroacetic acid $(958 \mu \mathrm{L}$, $12.4 \mathrm{mmol}$ ) was added. After the mixture being stirred for $3 \mathrm{~h}$, saturated $\mathrm{NaHCO}_{3}$ solution was added and the mixture was extracted with ethyl acetate $(50 \mathrm{~mL} \times 3)$. The organic layers were dried over anhydrous $\mathrm{MgSO}_{4}$ and concentrated. Removal of organic solvents from the residue gave the building block 5 (320 mg, 100\%).

${ }^{1} \mathrm{H}$ NMR (300 MHz, MeOD) $\delta 7.23(\mathrm{t}, 2 \mathrm{H}, J=8.0 \mathrm{~Hz})$, $6.96(\mathrm{~d}, 2 \mathrm{H}, J=7.8 \mathrm{~Hz}), 6.83(\mathrm{t}, 1 \mathrm{H}, J=7.3 \mathrm{~Hz}), 3.38-3.35$ $(\mathrm{m}, 1 \mathrm{H}), 3.25-3.21(\mathrm{~m}, 1 \mathrm{H}), 3.20(\mathrm{t}, 4 \mathrm{H}, J=5.0 \mathrm{~Hz}), 2.98-$ $2.87(\mathrm{~m}, 1 \mathrm{H}), 2.82-2.72(\mathrm{~m}, 2 \mathrm{H}), 2.63-2.49(\mathrm{~m}, 3 \mathrm{H}), 2.46$ $(\mathrm{dd}, 1 \mathrm{H}, J=13.5 \mathrm{~Hz}, J=4.0 \mathrm{~Hz}), 1.88(\mathrm{~d}, 3 \mathrm{H}, J=10.4 \mathrm{~Hz})$, 1.73-1.28 (m, 3H). ${ }^{13} \mathrm{C}$ NMR (75 MHz, MeOD) $\delta 152.7$, 130.0, 121.0, 117.5, 61.1, 54.9, 54.6, 50.4, 45.9, 28.5, 24.1, 23.1. IR (KBr) 1687, 1598, 1505, 1235, 1200, 1172, 1128 , $756 \mathrm{~cm}^{-1}$. ESI-MS $260.39(\mathrm{M}+1)$.

Other [piperazin-1-ylmethyl]piperidine derivatives were synthesized analogously and identified with the ${ }^{1} \mathrm{H}$ NMR, ${ }^{13} \mathrm{C}$ NMR, IR, and MS spectroscopies.

General Procedure for Synthesis of Building Block 9 (when $R_{2}=2$-methoxyphenyl). To a solution of 2-methoxybenzaldehyde oximes 7 (when $\mathrm{R}_{2}=2$-methoxyphenyl, $302 \mathrm{mg}, 2.00 \mathrm{mmol})$ in THF $(7 \mathrm{~mL})$ at $\mathrm{rt}$ under nitrogen atmosphere, $N$-chlorosuccinimide $(534 \mathrm{mg}, 2.00 \mathrm{mmol})$ and pyridine $(16.0 \mu \mathrm{L}, 0.20 \mathrm{mmol})$ were added. After being stirred for $1 \mathrm{~h}$ at $60{ }^{\circ} \mathrm{C}$, the mixture was cooled to $\mathrm{rt}$ and a solution of propargyl alcohol $(116 \mu \mathrm{L}, 2.00 \mathrm{mmol})$ in THF $(2 \mathrm{~mL})$ and triethylamine $(335 \mu \mathrm{L}, 2.40 \mathrm{mmol})$ in THF (2 $\mathrm{mL}$ ) were added dropwise successively. After the mixture being stirred at $50{ }^{\circ} \mathrm{C}$ for $3 \mathrm{~h}$, saturated $\mathrm{NaHCO}_{3}$ solution was added and the mixture was extracted with ethyl acetate $(50 \mathrm{~mL} \times 3)$. The organic layers were dried over anhydrous $\mathrm{MgSO}_{4}$ and concentrated. The residue was purified by flash column chromatography (Hexane:EtOAc $=1: 1)$ to give the isoxazole alcohol $\mathbf{8}(333 \mathrm{mg}, 81 \%)$.

To a solution of thus prepared alcohol 8 (when $\mathrm{R}_{2}=2$ methoxyphenyl, $261 \mathrm{mg}, 1.27 \mathrm{mmol}$ ) in dichloromethane $(10 \mathrm{~mL})$ at $\mathrm{rt}$, pyridinium chlorochromate $(548 \mathrm{mg}, 2.54$ mmol) and silica gel (230-400 mesh, $548 \mathrm{mg}$ ) were added. After being stirred for $6 \mathrm{~h}$, the mixture was filtered through Florisil column. The filtrate was concentrated and the residue was purified by flash column chromatography (Hexane:EtOAc $=2: 1$ ) to give the building block 9 (when $\mathrm{R}_{2}$ =2-methoxyphenyl, $195 \mathrm{mg}, 76 \%$ ).

${ }^{1} \mathrm{H} \mathrm{NMR}\left(400 \mathrm{MHz}, \mathrm{CDCl}_{3}\right) \delta 9.93(\mathrm{~s}, 1 \mathrm{H}), 7.88$ (dd, 1H, $J=7.7 \mathrm{~Hz}, J=1.7 \mathrm{~Hz}), 7.44$ (s, 1H), 7.41-7.35 (m, 1H), 7.01$6.92(\mathrm{~m}, 2 \mathrm{H}), 3.84(\mathrm{~s}, 3 \mathrm{H}) .{ }^{13} \mathrm{C}$ NMR $\left(100 \mathrm{MHz}, \mathrm{CDCl}_{3}\right) \delta$ 178.7, 165.3, 160.7, 157.2, 132.1, 129.4, 121.1, 116.4, 111.5, 110.9, 55.6. IR (KBr) 1697, 1602, 1501, 1472, 1296, 1267, 
$1252,1023,763,749 \mathrm{~cm}^{-1}$.

Other isoxazole aldehyde derivatives were synthesized analogously and identified with the ${ }^{1} \mathrm{H} \mathrm{NMR},{ }^{13} \mathrm{C} \mathrm{NMR}$, and IR spectroscopies.

General Procedure for Synthesis of Isoxazolylpiperidinylpiperazine derivatives 10 (when $R_{1}=P h$ and $R_{2}=\mathbf{2}$ methoxyphenyl). To a solution of building block $\mathbf{5}$ (when $\mathrm{R}_{1}=\mathrm{Ph}, 45.0 \mathrm{mg}, 0.17 \mathrm{mmol}$ ) and building block 9 (when $\mathrm{R}_{2}=2$-methoxyphenyl, $32.0 \mathrm{mg}, 0.16 \mathrm{mmol}$ ) in dichloromethane $(3 \mathrm{~mL})$ at rt, $4 \AA$ molecular sieve was added. After the mixture being stirred for $10 \mathrm{~min}, \mathrm{NaBH}(\mathrm{OAc})_{3}(100 \mathrm{mg}$, $0.47 \mathrm{mmol}$ ) was added and the mixture was stirred for $5 \mathrm{~h}$. Saturated $\mathrm{NaHCO}_{3}$ solution was added and the mixture was extracted with ethyl acetate $(5 \mathrm{~mL} \times 5)$. The organic layers were dried over anhydrous $\mathrm{MgSO}_{4}$ and concentrated. The residue was purified by flash column chromatography (EtOAc) to give the isoxazolylpiperidinylpiperazine $\mathbf{1 0}$ (when $\mathrm{R}_{1}=$ $\mathrm{Ph}$ and $\mathrm{R}_{2}=2$-methoxyphenyl, $45.6 \mathrm{mg}, 65 \%$ ).

${ }^{1} \mathrm{H}$ NMR (400 MHz, MeOD) $\delta 7.77(\mathrm{dd}, 1 \mathrm{H}, J=7.7 \mathrm{~Hz}, J$ $=1.7 \mathrm{~Hz}), 7.42(\mathrm{t}, 1 \mathrm{H}, J=7.0 \mathrm{~Hz}), 7.19(\mathrm{dd}, 2 \mathrm{H}, J=8.7 \mathrm{~Hz}$, $J=7.3 \mathrm{~Hz}), 7.08(\mathrm{~d}, 1 \mathrm{H}, J=8.3 \mathrm{~Hz}), 7.01(\mathrm{td}, 1 \mathrm{H}, J=7.5$ $\mathrm{Hz}, J=0.9 \mathrm{~Hz}), 6.91(\mathrm{~d}, 2 \mathrm{H}, J=7.9 \mathrm{~Hz}), 6.83-6.77(\mathrm{~m}, 2 \mathrm{H})$, $4.20(\mathrm{~d}, 1 \mathrm{H}, J=15.4 \mathrm{~Hz}), 4.00(\mathrm{~d}, 1 \mathrm{H}, J=15.3 \mathrm{~Hz}), 3.82$ (s, $3 \mathrm{H}), 3.11(\mathrm{t}, 4 \mathrm{H}, J=5.0 \mathrm{~Hz}), 3.93-3.85(\mathrm{~m}, 1 \mathrm{H}), 2.79(\mathrm{dd}$, $1 \mathrm{H}, J=13.0 \mathrm{~Hz}, J=5.8 \mathrm{~Hz}), 2.65-2.57(\mathrm{~m}, 2 \mathrm{H}), 2.57-2.44$ $(\mathrm{m}, 3 \mathrm{H}), 2.33(\mathrm{td}, 1 \mathrm{H}, J=11.3 \mathrm{~Hz}, J=3.0 \mathrm{~Hz}), 2.55(\mathrm{dd}, 1 \mathrm{H}$, $J=13.0 \mathrm{~Hz}, J=5.1 \mathrm{~Hz}), 1.84-1.73(\mathrm{~m}, 1 \mathrm{H}), 1.73-1.63(\mathrm{~m}$, $1 \mathrm{H}), 1.63-1.54(\mathrm{~m}, 1 \mathrm{H}), 1.54-1.45(\mathrm{~m}, 1 \mathrm{H}), 1.36-1.23(\mathrm{~m}$, 2H). ${ }^{13} \mathrm{C} \mathrm{NMR}\left(100 \mathrm{MHz}, \mathrm{CDCl}_{3}\right) \delta 170.7,161.3,158.7$, 152.2, 132.6, 130.2, 130.0, 121.9, 120.9, 118.9, 117.3,112.9, $106.5,63.8,58.3,56.1,55.0,54.4,50.5,50.0,32.0,26.2$, 24.6. IR (KBr) 2923, 2818, 1599, 1505, 1495, 1471, 1456, $1252,1152,1117,1025,1010,756,739 \mathrm{~cm}^{-1}$. ESI-MS 447.43 $(\mathrm{M}+1)$.

Other isoxazolylpiperidinylpiperazine derivatives were synthesized analogously and identified with the ${ }^{1} \mathrm{H}$ NMR, ${ }^{13} \mathrm{C}$ NMR, IR, and MS spectroscopies.

\section{References}

1. Sokoloff, P.; Giros, B.; Martres, M. P.; Bouthenet, M. L.; Schwartz, J. C. Nature 1990, 347, 146-151.

2. Schwarz, J. C.; Levesque, D. Clin. Neuropharmacol. 1993, 16, 295-314.
3. Levant, B. Pharmacol. Rev. 1997, 49, 231-252.

4. Van Tol, H. H. M.; Bunzow, J. R.; Guan, H. C.; Sunahara, R. K.; Seeman, P.; Niznik, H. B.; Civelli, O. Nature 1991, 350, 610-614.

5. (a) Enguehard-Gueiffier, C.; Hübner, H.; El Hakmaoui, A.; Allouchi, H.; Gmeiner, P.; Argiolas, A.; Melis, M. R.; Gueiffier, A. J. Med. Chem. 2006, 49, 3938-3947. (b) Löber, S.; Hübner, H.; Gmeiner, P. Bioorg. Med. Chem. Lett. 2006, 16, 2955-2959. (c) Mohr, P.; Decker, M.; Enzensperger, C.; Lehmann, J. J. Med. Chem. 2006, 49, 2110-2116. (d) Leopoldo, M.; Lacivita, E.; Colabufo, N. A.; Beradi, F.; Perrone, R. J. Pharm. Pharmacol. 2006, 58, 209-218. (e) Chen, J.; Ding, K.; Levant, B.; Wang, S. Bioorg. Med. Chem. Lett. 2006, 16, 443-446. (f) Lentz, C.; Boeckler, F.; Hübner, H.; Gmeiner, P. Bioorg. Med. Chem. 2005, 13, 4434-4442. (g) Wang, X.; Bhatia, P. A.; Daanen, J. F.; Latsaw, S. P.; Rhode, J.; Kolsa, T.; Hakeem, A. A.; Matulenko, M. A.; Nakane, M.; Uchic, M. E.; Miller, L. N.; Chang, R.; Moreland, R. B.; Brioni, J. D.; Stewart, A. O. Bioorg. Med. Chem. 2005, 13, 4667-4678. (h) Ding, K.; Chen, J.; Ji, M.; Wu, X.; Varady, J.; Yang, C. Y.; Lu, Y.; Deschamps, J. R.; Levant, B.; Wang, S. J. Med. Chem. 2005, 48, 3171-3181. (i) Bettinetti, L.; Löber, S.; Hübner, H.; Gmeiner, P. J. Comb. Chem. 2005, 7, 309-316. (j) Ji, M.; Chen, J.; Ding, K.; Wu, X.; Varady, J.; Levant, B.; Wang, S. Bioorg. Med. Chem. Lett. 2005, 15, 1701-1705. (k) Chu, W.; Tu, Z.; McElveen, E.; Xu, J.; Taylor, M.; Luedtke, R. R.; March, R. H. Bioorg. Med. Chem. 2005, 13, 77-87.

6. Liégeois, J.-F.; Eyrolles, L.; Bruhwyler, J.; Delarge, J. Curr. Med. Chem. 1998, 5, 77-100.

7. Seeman, P.; Guan, H. C.; Van Tol, H. H. M. Nature 1993, 365, 441-445.

8. Reynolds, G. P.; Mason, S. L. Eur. J. Pharmacol. 1995, 281, R5R6.

9. Seeman, P.; Guan, H. C.; Van Tol, H. H. M. Eur. J. Pharmacol. 1995, 286, R3-R5.

10. Sumiyoshi, T.; Stockmeier, C. A.; Overholser, J. C.; Thompson, P. A.; Meltzer, H. Y. Brain Res. 1995, 681, 109-116.

11. (a) Cha, M. Y.; Choi, B. C.; Kang, K. H.; Pae, A. N.; Choi, K. I.; Cho, Y. S.; Koh, H. Y.; Lee, H. Y.; Jung, D.; Kong, J. Y. Bioorg. Med. Chem. Lett. 2002, 12, 1327-1330. (b) Youn, H. S.; Lee, E. J.; Lee, J. E.; Park, W.-K.; Baek, D. J.; Cho, Y. S.; Koh, H. Y.; Choo, H.; Pae, A. N. Bull. Kor. Chem. Soc. 2009, 30, 1873-1876.

12. Kang, K. H.; Pae, A. N.; Choi, K. I.; Cho, Y. S.; Chung, B. Y.; Lee, J. E.; Jung, S. H.; Koh, H. Y.; Lee, H. Y. Tetrahedron Lett. 2001, 42, 1057-1060.

13. Abdel-Magid, A. F.; Carson, K. G.; Harris, B. D.; Maryanoff, C. A.; Shah, R. D. J. Org. Chem. 1996, 61, 3849-3862.

14. The generated isoxazolylpiperidinylpiperazine analogues were evaluated in vitro for dopamine $\mathrm{D}_{3}-\mathrm{D}_{4}$ receptors binding affinity by measuring their ability to displace radioligands $\left(\left[{ }^{3} \mathrm{H}\right]\right.$ spiperone for $D_{4},\left[{ }^{3} \mathrm{H}\right] \mathrm{YM}-09151-2$ for $\mathrm{D}_{3}$ ) from the cloned human dopamine receptors $\mathrm{D}_{3}$ and $\mathrm{D}_{4.2}$ which were expressed in $\mathrm{CHO}$ cells, respectively. 